\title{
Diseases of echinoderms
}

\author{
M. Jangoux \\ Laboratoire de Biologie marine, Université Libre de Bruxelles; \\ $B-1050$ Brussels, Belgium
}

\begin{abstract}
Diseases of echinoderms are poorly documented. Most reports concern biotic diseases caused by animal agents. While parasites on echinoderms have been described in increasing numbers of papers for more than one century, the host-parasite relationship and the effects of parasitism on echinoderm life-cycles were rarely considered. The parasitic fauna differs markedly according to the echinoderm group concerned, depending on various factors such as feeding-habits or symbiogenesis. Microorganismic diseases undoubtedly occur in echinoderms but they were not investigated until recently. Microorganisms have frequently been assumed to act as agents causing mass mortalities. As for stress-caused diseases, the only - and very preliminary - data available concern almost exclusively those induced by pollution. Since echinoderms are major components of benthic ecosystems, echinoderm diseases may be expected to exert prominent ecological effects.
\end{abstract}

\section{INTRODUCTION}

Recent echinoderms belong to three different classes, viz. Crinozoa, Echinozoa and Asterozoa. They number together about 6500 species. Echinoderms are macroinvertebrates that occur everywhere on the sea floor. Here they often live in dense populations. They constitute a major group of benthic animals representing an important biomass in many areas. Echinoderms, especially echinoids and ophiuroids, form part of the diet of many fishes and macroinvertebrates such as crustaceans. Echinoderms and, therefore, echinoderm diseases are worth investigating both biologically and ecologically.

Thus far, the reported diseases of echinoderms are essentially biotic diseases caused by animal agents. A few conspicuous infestations of the body wall supposedly caused by microorganisms have also become known. Non-biotic diseases are mainly caused by pollutants and as yet undefined factors which produce test deformations in echinoids.

\section{DISEASES CAUSED BY MICROORGANISMS}

Non-pathological bacteria naturally occur in echinoderms, e.g. gut-associated bacteria of regular echinoids (Guerinot \& Patriquin, 1981) or subcuticular bacteria observed in most echinoderms (Holland \& Nealson, 1978). However, healthy individuals never have bacteria in their coelomic fluid which is normally aseptic (Wardlaw \& Unkles, 1978).

No published data have come to the reviewer's attention that demonstrate clearly the presence of microorganismic diseases affecting echinoderms in the field. However, some echinoderm mass mortalities have been suggested to be due to microorganisms, 
e.g. in the asteroid Heliaster kubinjii (Dungan et al., 1982) and several species of echinoids (Johnson, 1971; Pearse et al., 1977; Höbaus et al., 1981; Maes \& Jangoux, 1984). These echinoids suffered from a conspicuous condition - the "bald-sea-urchin" disease - that alters the outer surface of the body wall.

It developes as follows (Johnson, 1971; Maes \& Jangoux, 1984): (1) green appearance of the epidermis surrounding some spine bases; (2) loss of spines and other outer appendages (tube-feet and pedicellariae) and occurrence of a green colour in epidermis and underlying dermal tissue; (3) loss of the epidermis and the superficial dermal tissue and formation of small circular to elongate denuded test areas; (4) partial destruction of the upper layer of the skeleton. If lesions progress more deeply or reach the weakly calcified peristomial or periproctal membranes, coelomic perforations may occur. Coelomic perforations often involve partial or whole evisceration of internal organs. Unaffected body wall areas appear normal with seemingly healthy epidermis and spines. Recovery of affected individuals - regeneration of body-wall tissues and outer appendages - may occur spontaneously in the field, presumably depending on size and location of the lesions.

\section{DISEASES CAUSED BY PROTOZOANS}

The only ciliate which definitely acts as an echinoderm parasite is the astomatous holotrich Orchitophyra stellarum found in the gonads of the asteroid Asterias rubens. The ciliate parasitizes mostly the testes in which it causes progressive breakdown of germinal tissue. Most infested asteroids are completely castrated (Vevers, 1951). Female gonads may also be affected but they are seemingly not destroyed as their eggs are said to be fertilizable (Smith, 1936). Given the economical interest in controlling populations of oyster- and mussel-eating asteroids, attempts were made at experimental infestations but they remained unsuccessful (Burrows, 1936).

Parasitic sporozoans occur only in holothuroids and spatangoid echinoids. So far they have never been observed in crinoids, asteroids nor ophiuroids. About two dozen species of sporozoan parasites are known from echinoderms, among these only one coccidian (Massin et al., 1978); the others are gregarines (e.g. Léger, 1897; Cuénot, 1912; Pixell-Goodrich, 1925; Changeux, 1961). Gregarine infestations are generally very intense - each host harboring many cysts - and affect almost all individuals of the host population. Deposit-feeding echinoderms are very sensitive to gregarine infestations. They may infest themselves by simply swallowing sediment containing mature cysts.

A more or less prolonged stay in the host hemal system appears to be necessary for gregarines parasitizing deposit-feeding holothuroids. In contrast, the life-cycle of gregarines from spatangoids seems to be simpler: the whole cycle occurs within the coelomic cavity. Whatever their cycle, parasitic sporozoans may induce host-defense reactions that are sometimes very conspicuous (e.g. the intracoelomic motile stages of some spatangoid-infesting gregarines are walled off by coelomocytes which progressively change their shape reaching a sharp-pointed aspect [De Ridder \& Jangoux, 1984]).

The pathogenicity of these sporozoans is difficult to assess, except when massinfestations occur (such as those described in holothuroids by Pixell-Goodrich [1925] and by Massin et al. [1978]). In these cases the hemal lacunae are distended by cysts and the hemal fluid is intensively used by the parasites for their own development. Such mass- 
infestation may affect the host's health by diverting and exploiting the energy flow of the holothuroid.

\section{DISEASES CAUSED BY METAZOANS}

Mesozoa ns. Only one species of mesozoan, viz. Rhopalura ophiocomae, parasitizes echinoderms. Its most frequent host is the small hermaphroditic and incubating ophiuroid Amphipholis squamata. Structure and life cycle of $R$. ophiocomae were intensively studied at the beginning of this century (Caullery \& Lavallée, 1912). Mature adult forms of $R$. ophiocomae are free living. Adults develop into infested $A$. squamata and are emitted through the ophiuroid genital slits. Adults are either male or female. They give rise to ciliated larvae which enter the genital slits and penetrate the wall of the genital bursae. They transform into small parasitic "plasmodia" (into which the socalled mesozoan embryos develop). The most obvious effect of $R$. ophiocomae is that it produces the regression of the host ovaries (testes remain functional). This ovarian regression implies that infested ophiuroids never harbor incubated embryos. Other consequences of that biotic disease are a decrease in the regenerative abilities of the ophiuroid as well as a probable decrease in its growth rate (Rader, 1982).

Turbellarians. Most of the symbiotic turbellarians living together with echinoderms are umagillid rhabdocoels (Jennings, 1971; Cannon, 1982). With very few exceptions, almost all echinoderm-associated turbellarians live either within the digestive tract or within the coelomic cavity of their host. Symbiotic turbellarians have been reported for each echinoderm group, but most inhabit aspidochirote holothuroids (Holothuria spp. and Stichopus spp. mainly) or regular echinoids.

Although massive infestations by turbellarians occur rather frequently in echinoderms, almost nothing is known on the agent-host relationships. Intracoelomic umagillids depend directly on their host for nutrition (they ingest coelomic fluid and coelomocytes; Mettrick \& Jennings, 1969). Gut-associated umagillids were considered classical commensals (Jennings, 1971). However, recent work indicates that they feed on intestinal tissues and are basically parasitic (Shinn, 1981; Cannon, 1982).

Tre m a todes. About a dozen species of digenic trematodes were reported from echinoderms. The latter act generally as second intermediary hosts (Timon-David, 1934; Køie, 1976). The peculiar location of metacercarian cysts (e.g. in muscles or body wall), as well as their small size, may partly explain why relatively few species of echinoderminfesting trematodes have been recorded. Whatever the cause, echinoderms are very suitable hosts for marine digenic trematodes. Not only do echinoderms occur frequently in dense populations, but also some of their representatives form part of the diet of many fishes. Actually most echinoderm-infesting trematodes are known from echinoids and ophiuroids which are the most usual echinoderm prey for fishes. The role of echinoderms as vector of fish diseases caused by trematodes requires investigation.

Nematodes. Echinoderm-associated nematodes are mostly juvenile forms (Ward, 1933). Presumably, echinoderms act as intermediary host, the primary host being fishes. This was demonstrated by Pearse \& Timm (1971) who identified the primary host of the gonad-infesting nematode of Centrostephanus coronatus as being the California horned shark Heterodontus francisci. They showed that growing juvenile nematodes progressively invade the echinoid gonadal tubules (small juveniles are confined to the gonad wall) and that this migration consequently affects host gametogenesis. Pearse \& 
Timm suggested that encysted juveniles block the passage through the tubules of some hormonal substance that regulates the host's gametogenesis.

My z o s t o m id s. The class Myzostomida (about 110 species described) occupies a peculiar place among echinoderm symbiotes. They are aberrant annelids with a small flattened body several $\mathrm{mm}$ in length. Their most extraordinary feature is their constant association with echinoderms - there are no free-living species of myzostomids nor any species associated with other phyla. Myzostomids mostly infest crinoids, but a few species are known from asteroids and ophiuroids. Myzostomids are highly differentiated organisms both morphologically and ecologically. Their almost obligatory association with crinoids suggests that they represent an ancient animal group which evolved together with crinoids. Myzostomids may certainly be considered as an unique case of "symbiogeneses" involving a whole class of organisms.

About 25 species of myzostomids are recorded as echinoderm parasites. Three kinds of parasitism may be defined, depending on whether the myzostomids are gallicole, cysticole or endoparasitic (Stummer-Traunfels, 1926). Endoparasitic species feed on host tissues, most often gonadal tissue. They cause at least a partial castration of the echinoderm (Fedotov, 1916). In contrast, gallicole and cystocole species are suspension feeders which divert the water currents produced by host ambulacra. Gallicole myzostomids dig into the dermal tissue of crinoid arms or pinnules. They build more or less spacious intradermal cavities, always located under the skeletal ossicles (Graff, 1884). Cysticole myzostomids build peculiar, stalked or unstalked cysts which always are subcutaneous (i.e. located outside the host skeleton) and protrude into the external medium (Graff, 1884; Stummer-Traunfels, 1926). Both gallicole and cysticole species induce major changes by altering the crinoid body wall. They may be expected to affect the movements of crinoid arms.

Gastropod mollus cs. Gastropods symbiotic with echinoderms belong almost exclusively to the family Eulimidae. According to Warén (1983) there are about 750 species (43 genera) of extant eulimids, many of which are associated with echinoderms. Most ectoparasitic eulimids are attached to the echinoderm body surface. They feed on host tissues or fluids using their proboscis which penetrates more or less deeply into the echinoderm body wall or crosses it to reach the coelomic cavity, the water-vascular system, or the hemal system (e.g. Tullis \& Cheng, 1971; Lützen \& Nielsen, 1975; Bouchet \& Lützen, 1976).

The most peculiar endoparasitic eulimids belong to the entoconchid group - the aberrant Entocolax and allied genera. They are intracoelomic parasites which occur only in asteroids and holothuroids (e.g. Lützen, 1979). Entocochids generally are believed to derive their energy requirements from the host's coelomic fluid by direct absorption of nutrients through the parasite's body wall.

The effects of parasitic gastropods obviously are not restricted to their feeding. Ectoparasitic eulimids may produce clearly defined attachment lesions (Elder, 1979). They may also cause dermal swellings or induce modifications of the host skeleton (Lützen, 1976 and Koehler \& Vaney, 1912, respectively). As for the intracoelomic entoconchids, Heding \& Mandhal-Barth (1938) considered that they may castrate their host, while Lützen (1979) concluded that they are not likely to influence holothuroid fecundity.

Copepod crustaceans. There is little documentation of the relationships 
between echinoderms and their symbiotic copepods. Most of the ectosymbiotic species were not proven to be parasites, except those inhabiting ophiuroid genital bursae (Pyefinch, 1940). A few species, however, induce gall formation in spines of echinoids (Stock, 1968) or dig into the dermis of asteroids (Röttger, 1969). With few exceptions (e.g. Paterson, 1958), intracoelomic copepods have been reported to be "free in the coelomic cavity" without seeming to induce any host reaction (e.g. intracoelomic copepods of holothuroids; Humes, 1980).

Effects of parasitic copepods on echinoderm life-cycles have hardly been considered. According to Goudey-Pèrrière (1980) the occurrence of Amphiurophilus amphiurae within the genital bursae of Amphipholis squamata does not affect the host's gonads but decreases its fecundity by inhibiting the development of incubated embryos. This could result from competition for food between parasite and embryos.

Ascothoracid crustaceans. Ascothoracids are "naked barnacles" that parasitize all groups of echinoderms, except holothuroids. They are known mostly from asteroids and spatangoid echinoids where they occur within the coelomic cavity. Brattström (1947) concluded that ascothoracids directly absorb nutrients form the coelomic fluid of their host, while Wagin (1976) believed that coelomocytes from the bulk of their diet. Ascothoracids which infest the branchial bursae of ophiuroids may cause castration of their host in producing the regression of the host's gonads (Wagin, 1946). Similar castration occurs in spatangoids parasitized by intracoelomic ascothoracids. According to Brattström (1947) castration results from competition for food (i.e. intracoelomic nutrients) between the spatangoid gonads and the parasite.

Ma la costracan crusta ceans. Malacostracan parasites of echinoderms are mainly small crabs which live either on the outer body surface or within the digestive system of echinoids and holothuroids. An obvious ectoparasitic relationship occurs between some crab species and echinoids, i.e. the crabs feed on the skin and the peripheral dermal tissues of their host and produce naked test areas. Such infestations often exert major effects and may kill echinoids (e.g. Dexter, 1977). Gut-inhabiting species are harmless although they may produce conspicuous deformations of the host's rectum. They are said to feed upon the digestive content of the echinoderm (Fenucci, 1967).

P is ces. Associations between echinoderms and carapid fishes (i.e. pearlfishes) are of very particular interest as it concerns - at least in some cases - typical parasitic relationships between an invertebrate host and a vertebrate (Trott, 1970, 1981). Carapus spp. inhabit the coelomic cavity of holothuroids and asteroids. They use the host's coelom as shelter and leave it in order to catch prey, feeding primarily on crustaceans. Carapus spp. cause only slight injury to the echinoderm in piercing its digestive wall when entering or leaving the coelomic cavity. In contrast, carapids of the genus Encheliophis are considered to be typical parasites. They stay permanently in the echinoderm coelom feeding on the viscera of their host (Trott, 1970).

\section{STRESS-CAUSED DISEASES}

Stress-caused diseases are induced by critical intensities of environmental conditions (Kinne, 1980). They include diseases caused by pollutants as well as those resulting in unsuitable variations of abiotic factors. Effects of pollutants on echinoderm health 
have been scarcely reported. Pollution effects were either observed in the field, or were experimentally induced under laboratory conditions. Laboratory investigations deal mainly with consequences of pollution caused by oil (crude or refined) or by heavy metals.

Massive oil pollution can destroy echinoderm populations (North et al., 1964). According to Axiak \& Saliba (1981), echinoids are unable to detect or avoid contact with surface or sunken oil. These authors showed moreover that contact with oil prolongs the echinoid righting response, decrease the adhesion capacity of tube-feet to the substrate and decrease the intensity of the spine response to local mechanical stimuli. Effects of crude oil or petroleum fractions on echinoid gametes, embryos or larvae have also been considered (e.g. Lönning \& Hagström, 1975; Crawford \& Muto, 1977). In summary, these substances generally exert moderate effects on gametes, fertilization and early embryos, but have harmful consequences in late embryos and early larval stages.

Field pollution by heavy metals was studied by Sheppard \& Bellamy (1974) near Naples. They reported the total absence of echinoids from typical biotopes in the heaviest polluted sites. Heavy metal pollution greatly affecting the echinoid Tripneuses gratilla was noted by Dafni (1980) in the Gulf of Aqaba. The echinoid skeleton showed conspicuous deformations, viz. bulging of the aboral part of the test, narrowing of the peristomial aperture and increase in size of the Aristotle's lantern. According to Dafni, the growth rate of deformed individuals is very low compared with that of normal ones. Effects of heavy metals on gametes and on various developmental stages of echinoids mostly plutei - were investigated by several authors (e.g. Bougis, 1967; Kobayashi, 1980; Castagna et al., 1981). These investigations showed that either gametes, embryos or larvae of echinoids are suitable material for marine pollution bioassays. Plutei were demonstrated to have a very sensitive and plastic skeleton which may change both in shape and its way of growth according to the tested heavy metal.

Populations of littoral echinoderms are positively affected by moderate organic (domestic) pollutions. Pearse et al. (1970) suggested that the high density of echinoids occurring in areas lacking kelp is a result of their ability to feed on sedimented organic matter carried by sewage. Harmelin et al. (1981) showed that in areas where pollution with domestic wastes is relatively moderate there is a high diversity of echinoderm species together with a high density of individuals of each species. An increase in organic pollution causes a decrease in species diversity together with an extension and a progressive size reduction of the more tolerant species.

\section{OTHER DISEASES}

Test abnormalities were reported for many species of regular and irregular echinoids especially by Koehler (1922) and Moore (1974). These abnormalities vary in type and severity; some individuals have pinched or bifurcated ambulacrum, others a depressed or distorted test, or a depressed apex. The authors mentioned agree that test alterations may have different causes, viz. external injuries, genetic malformations, critical environmental conditions, or be due to biotic or nutritional diseases. That test abnormalities can be caused by malnutrition was emphasized by Koehler, while Moore considered they would result mainly from metabolic disturbance. Whatever the cause, 
the fact that these abnormalities are not uncommon indicates that the echinoid test has great plasticity.

\section{ECOLOGICAL CONSEQUENCES OF ECHINODERM DISEASES}

The ecological consequences of echinoderm diseases have not been studied to any large extent. Most diseases caused by animal agents are seemingly well tolerated and do not produce major consequences for the echinoderm population concerned. Some agents, however, may castrate echinoderms and consequently will affect renewal and long-term stability of the population. Other non-castrating agents such as arm-infesting myzostomids, bursal-inhabiting copepods or coelom-parasitizing ascothoracids, obviously should weaken their host population. However, quantitative estimations of the effects of these agents have never been reported.

Echinoderm diseases may also affect the predators of echinoderms. This is true particularly for echinoderms affected by communicable diseases, especially those caused by digenic trematodes and by nematodes (as stated above, echinoderms are suitable hosts for these parasites as numerous echinoid and ophiuroid species form part of the diet of many fishes). This may also concern contaminated echinoderms, i.e. echinoderms that would concentrate chemical pollutants (e.g. heavy metals: Bohn, 1979; radionuclides: Guary et al., 1982) either through the food-chain or directly through the water-column.

Littoral echinoderms are frequently top predators in their community (viz. many paxillosid and forcipulatid asteroids), or controlling agents of seagrass or kelp beds (viz. numerous regular echinoids). Removal of these predators may produce major environmental changes (e.g. Paine, 1971). Mass mortalities by diseased echinoids were investigated ecologically by Pearse \& Hines (1979) who reported that the death of echinoids was followed by rapid expansion of four species of brown algae. Competition among algal species was severe, and within one year only a single species colonized the area. According to Miller \& Colodey (1983), mass mortality of echinoids in a rocky habitat in Nova Scotia is expected to result in colonization by subtidal algae with a subsequent increase in benthic primary production.

Echinoderms are major components of many benthic ecosystems. Their diseases can be expected to have prominent ecological consequences.

\section{LITERATURE CITED}

Axiak, V. \& Saliba, L. J., 1981. Effects of surface and sunken crude oil on the behaviour of a sea urchin. - Mar. Pollut. Bull. 12, 14-18.

Bohn, A., 1979. Trace metals in fucoid algae and purple sea urchins near a high Arctic lead/zinc ore deposit. - Mar. Pollut. Bull. 10, 325-327.

Bouchet, P., Lützen, J., 1976. Pisolamia, nouveau genre de gastéropode parasite de l'holothurie abyssale Oneirophanta mutabilis, - C. r. hebd. Séanc. Acad. Sci., Paris 282, 1013-1016.

Bougis, P., 1967. Utilisation des plutéus en écologie expérimentale. - Helgoländer wiss. Meeresunters. $15,59-68$.

Brattström, H., 1947. On the ecology of the ascothoracid Ulophysema oresundense Brattström. Lunds Univ. Aarskr. 43 (7), 1-75.

Burrows, R. B., 1936. Further observations on parasitism in the starfish. - Science, N. Y. 84, 329. 
Cannon, L. R., 1982. Endosymbiotic umagillids (Turbellaria) from holothurians of the Great Barrier Reef, - Zool. Scr. 11, 173-188.

Castagna, A., Sinatra, F., Scalia, M. \& Capodicasa, V., 1981. Observations of the effect of Zinc on the gametes and various development phases of Arbacia lixula. - Mar. Biol. 64, 285-289.

Caullery, M. \& Lavellée, A., 1912. Recherches sur le cycle évolutif des orthonectides. Les phases initiales de l'infestation expérimentale de l'ophiure Amphiura squamata par Rhopalura ophiocomae - Bull. scient. Fr. Belg. 46, 139-171.

Changeux, J. P., 1961. Contribution à l'étude des animaux associés aux holothurides. - Vie Milieu (Suppl.) 10, 1-124.

Crawford, R. B. \& Muto, M. G., 1977. Effects of water soluble fractions from crude oil on development of sand dollar embryos. - Bull. Mt Desert Isl. biol. Lab. 17, 112-115.

Cuénot, L., 1912. Contribution à la faune du Bassin d'Arcachon. V. Echinodermes. - Bull. Stn biol. Arcachon 14, 17-116.

Dafni, J., 1980. Abnormal growth patterns in the sea urchin Tripneustes cf, gratilla (L.) under pollution (Echinodermata, Echinoidea), - J. exp. mar. Biol. Ecol. 47, 259-279.

Dexter, D. M., 1977. A natural history of the sand dollar, Encope stockesi L. Agassiz in Panama. Bull. mar. Sci. 27, 544-551.

Dungan, M. L., Miller, T. E. \& Thomson, D. A., 1982. Catastrophic decline of a top carnivore in the Gulf of California rocky intertidal zone. - Science, N. Y. 216, 989-991.

Elder, H, 1979. Studies on the host-parasite relationship between the parasitic prosobranch Thyca crystallina and the asteroid starfish Linckia laevigata. - J. Zool., Lond. 187, 369-391.

Fedotov, D. M., 1916. On the parasitim of Protomyzostomum in Gorgonocephalus eucnemis M. Tr. Zool. Zh. 1, 161-218 (in Russ. with Engl. summary).

Fenucci, J. L., 1967. Contribution al conocimiento del crustaceo decapodo braquiuro Pinnaxodes chilensis (M. Edwards), comensal de Loxechinus albus (Molina) (Echinodermata, Echinoidea). Physis, B. Aires 27, 125-133.

Goudey-Perrière, F., 1980. Modalités de l'infestation de l'ophiure Amphipholis squamata Delle Chiaje, échinoderme, par le crustacé copépode Amphiurophilus amphiurae (Hérouard) et influence du parasite sur l'état de gravidité de l'hôte. - C. r. hebd. Seánc. Acad. Sci., Paris 291, $697-700$

Graff, L. von, 1884. Report on the Myzostomida. - Rep. scient. Results Voyage HMS Challenger (Zool.) 10, 1-82.

Guary, J. C., Fowler, S. W. \& Beaslay, T. M., 1982. Routes of plutonium uptake and their relation to biomagnification in starfish. - Mar. Pollut. Bull. 13, 99-102.

Guerinot, M. L., Patriquin, D. G., 1981. The association of $\mathrm{N}_{2}$-fixing bacteria with sea-urchins. Mar. Biol. 62, 197-207.

Harmelin, J. G., Bouchon, C. \& Hong, J. S., 1981, Impact de la pollution sur la distribution des échinodermes des substrats durs en Provence (Méditerranée Nord-occidentale). - Téthys 10, 13-36.

Heding, S. G. \& Mandahl-Barth, G., 1938. Investigations on the anatomy and systematic position of the parasitic snail Entocolax Voigt. - Meddr Grønland 108 (5), 1-40.

Höbaus, E., Fenaux, L. \& Hignette, M., 1981. Premières observations sur les lésions provoquées par une maladie affectant le test des oursins en Méditerranée occidentale. - Rapp. P.-v, Réun. Commn int. Explor. scient. Mer Méditerr. 27, 221-222.

Holland, N. D. \& Nealson, K. H., 1978. The fine structure of the echinoderm cuticle and the subcuticular associated bacteria of echinoderms. - Acta Zool, Stockh. 59, 169-185.

Humes, A. G., 1980. A review of the copepods associated with holothurians, including new species from the Indo-Pacific. - Beaufortia 30, 31-123.

Jennings, J. B., 1971. Parasitism and commensalism in Turbellaria. - Adv. Parasitol. 9, 1-32.

Johnson, P. T., 1971. Studies on diseased urchins from Point Loma. - A. Rep. Calif. Inst. Technol., Pasadena 1970-1971, 82-90.

Kinne, O., 1980. Diseases of marine animals: general aspects. In: Diseases of marine animals. Ed. by O. Kinne. Wiley, Chichester, 1, 13-73.

Kobayashi, N., 1980. Comparative study of various developmental stages of sea urchins to some chemicals. - Mar. Biol. 58, 163-171. 
Koehler, R., 1922. Anomalies et irrégularités du test des échinides. - Bull. Inst. océanogr. Monaco $419,1-158$.

Koehler, R. \& Vaney, C., 1912. Nouvelles formes de gastéropodes ectoparasites. - Bull. scient. Fr. Belg. 46, 191-217.

Køie, M., 1976. On the morphology and life-history of Zoogonoides viviparus (Olsson 1868) Odhner, 1922 (Trematoda, Zoogonidae). - Ophelia 15, 1-14.

Léger, L., 1897. Contribution à la connaissance des sporozoaires parasites des échinodermes. Etude sur le Lithocystis schneideri. - Bull. scient. Fr. Belg. 30, 24-264.

Lönning, S. \& Hagström, B. E., 1975. The effects of crude oils and the dispersant Corexit 8666 on sea urchin gametes and embryos. - Norw. J. Zool. 23, 121-129.

Lützen, J., 1976. On a new genus and two new species of Prosobranchia (Mollusca), parasitic on the tropical sea urchin Echinometra mathaei. - Israël J. Zool. 25, 38-51.

Lützen, J, 1979. Studies on the life-history of Enteroxenos Bonnevie, a gastropod endoparasitic in aspidochirote holothurians, - Ophelia 18, 1-51.

Lützen, J. \& Nielsen, K., 1975. Contributions to the anatomy and biology of Echineulima n. g. (Prosobranchia:Eulimidae), parasitic on sea urchins. - Vidensk. Meddr dansk naturh. Foren. $138,171-199$.

Maes, P. \& Jangoux, M, 1984. The bald-sea-urchin disease: a biopathological approach, - Helgoländer Meeresunters. 37, 217-224.

Massin, C., Jangoux, M. \& Sibuet, M., 1978. Description d'Ixoreis psychropotae, nov. gen., nov. sp., coccidie parasite du tube digestif de l'holothure abyssale Psychropotes longicauda Théel. Protistologica 14, 253-259.

Mettrick, D. F. \& Jennings, J. B., 1969. Nutrition and chemical composition of the rhabdocoel turbellarian Syndesmis franciscana, with notes on the taxonomy of $S$. antillarum. - J. Fish. Res. Bd Can. 26, 2669-2679.

Miller, R. J. \& Colodey, A. C., 1983. Widespread mass mortalities of the green sea urchin in Nova Scotia, Canada. - Mar. Biol. 73, 263-267.

Moore, H. B., 1974. Irregularities in the test of regular sea urchins. - Bull. mar. Sci. 24, 545-567.

North, W. J, Neushul, M. \& Clendenning, K. A., 1964. Successive biological changes observed in a marine cove exposed to a large spillage of oil. - Symp. Commn int. Explor. scient. Mer Méditerr. Monaco 1964, 335-354.

Paine, R. T., 1971. A short-term experimental investigation of resource partitioning in a New Zealand rocky intertidal habitat. - Ecology 52, 1096-1106.

Paterson, N. F., 1958. External features and life-cycle of Cucumaricola notabilis nov. gen. et sp., a copepod parasite of the holothurian, Cucumaria. - Parasitology 48, 269-290.

Pearse, J. S., Clark, M. E., Leighton, D. L., Mitchell, C. T. \& North, W. J., 1970. Marine waste disposal and sea-urchin ecology, - A. Rep. Calif. Inst. Technol., Pasadena 1969-1970, appendix $1-87$.

Pearse, J. S., Costa, D. P., Yellin, M. B. \& Agegian, C. R., 1977. Localized mass mortality of red sea urchin, Strongylocentrotus franciscanus, near Santa Cruz, California. - Fish. Bull. U. S. 75, $645-648$.

Pearse, J. S. \& Hines, A. H., 1979. Expansion of a central California kelp forest following the mass mortality of sea urchins. - Mar. Biol. 51, 83-91.

Pearse, J. S. \& Timm, R. W., 1971. Juveniles nematodes (Echinocephalus pseudouncinatus) in the gonads of sea urchins (Centrostephanus coronatus) and their effect on host gametogenesis. Biol. Bull. mar. biol. Lab., Woods Hole 140, 95-103.

Pixell-Goodrich, H. L., 1925. Observations on the gregarines of Chirodota. - Q. Jl microsc. Sci. 69, $620-628$.

Pyefinch, K. A., 1940. The anatomy of Ophioica asymetrica, n. sp., a copepod endoparasitic in an ophiuroid. - J. Linn. Soc. (Zool.) 41, 1-19.

Rader, D. N., 1982. Orthonectid parasitism: effects on the ophiuroids. In: Proceedings of the international chinoderm conference, Tampa Bay, 1981. Balkema, Rotterdam, 395-401.

Ridder, C. de \& Jangoux, M., 1984. Intracoelomic parasitic Sporozoa in the burrowing spatangoid, Echinocardium cordatum (Pennant) (Echinodermata, Echinoidea): coelomocyte reaction and formation of brown bodies. - Helgoländer Meeresunters. 37, 225-231.

Röttger, R., 1969. Okologie und Postlarvalentwicklung von Scottomyzon gibberum, eines auf 
Asterias rubens parasitisch lebenden Copepoden (Cyclopoida, Siphonostoma). - Mar. Biol. 2, 145-202.

Sheppart, C. R. \& Bellamy, D. J., 1974. Pollution of the Mediterranean around Naples. - Mar. Pollut. Bull. 5, 42-44.

Shinn, G. L., 1981. The diet of three species of umagillid neorhabdocoel turbellarians inhabiting the intestine of echinoids. - Hydrobiologia 84, 155-162.

Smith, G. F., 1936. A gonad parasite of the starfish. - Science, N. Y. 84, 157.

Stock, J. H., 1968. The Calvocheridae, a family of copepods inducing galls in sea-urchin spines. Bijdr. Dierk. 38, 84-90.

Stummer-Traunfels, R. R. von, 1926. Myzostomida. In: Handbuch der Zoologie. Hrsg. von W. Kükenthal. De Gruyter, Berlin, 3 (1), 132-210.

Timon-David, J., 1934. Recherches sur les Trématodes parasites des oursins en Méditerranée. Bull. Inst. océanogr. Monaco 652, 1-16.

Trott, L. B., 1970. Contributions to the biology of carapid fishes (Paracanthopterygii : Gadiformes) Univ. Calif. Publs Zool. 89, 1-41.

Trott, L. B., 1981. A general review of the pearlfishes (Pisces, Carapidae). - Bull mar. Sci. 31, $623-629$.

Tullis, R. E. \& Cheng, T. C., 1971. The uptake of ${ }^{14} \mathrm{C}$ by Stylifer linckiae (Mollusca: Prosobranchia) from its echinoderm host, Linckia multifora. - Comp. Biochem. Physiol. 40B, 109-112.

Vevers, H. G., 1951. The biology of Asterias rubens. II. Parasitization of the gonads by the ciliate Orchitophyra stellarum Cépède. - J. mar. biol. Ass. U. K. 29, 619-624.

Wagin, V. L., 1946. Ascothorax ophioctenis and the position of Ascothoracida Wagin in the system of the Entomostracea. - Acta Zool., Stockh. 27, 155-267.

Wagin, V. L., 1976. Ascothoracida. Kazan Univ. Press, Kazan (USSR), 141 pp. (In Russ.).

Ward, H. B., 1933. On Thalassonema ophioctenis, a nematodes parasitic in the brittle-star, Ophiocten amitinum. - J. Parasit, 19, 262-268.

Wardlaw, A. C. \& Unkles, S. E., 1978. Bactericidal activity of coelomic fluid from the sea urchin Echinus esculentus. - J. invertebr. Pathol. 32, 25-34.

Warén, A., 1933. A generic revision of the family Eulimidae. - J. moll. Stud. (Suppl.) 13, 1-96. 